\title{
O AGENDAMENTO E A PARTICIPAÇÃO DO PÚBLICO NOS TELEJORNAIS: DAS CARTAS AO FALE CONOSCO
}

\author{
SCHEDULLING AND AUDIENCE PARTICIPATION ON TV NEWS: FROM \\ THE LETTERS TO CONTACT US
}

Paulo Eduardo Silva Lins Cajazeira*

\begin{abstract}
RESUMO
Ao pensar o advento das novas mídias digitais, este artigo estuda a participação do telespectador colaborativo por meio do ícone Fale Conosco, cujo conteúdo pode ser utilizado ou não na estrutura do texto jornalístico em TV. A relevância deste trabalho consiste em analisar as mudanças ocorridas na produção dos telejornais com a participação do público, considerando as seguintes hipóteses: 1) a troca de papéis comunicativos, assumidos por destinadores e destinatários, se evidencia na construção do enunciado e determinam uma alteração nas rotinas produtivas dos telejornais com a criação de novos ambientes midiáticos tecnodigitais; 2) a participação do público é responsável por simular uma visibilidade, representada pela exibição do conteúdo colaborativo e manipulada pelos telejornais. Busca-se, assim, verificar os critérios de seleção dos enunciados realizados por destinadores (jornalistas) e destinatários (público), mediante o suporte dos espaços interativos, criados pelas próprias empresas de comunicação nos telejornais em TV e na Internet.
\end{abstract}

Palavras-chave: Telejornalismo. Participação. Internet.

\begin{abstract}
Considering the advent of the new digital medias, this paper studies the participation of the collaborative viewer through the "Contact Us" icon whose content can be used or not in the structure of texts in TV journalism. The relevance of this work consists in the analysis of the changes in the production of news programs with the participation of the public considering the following assumptions: 1) the change of communicative roles assumed by addressers and intended recipients that is evident in the construction of statements and determine a change in the production routines of television news with the creation of new technodigital media environments; 2) public participation is responsible for simulating a visible display which is represented by the exhibition of collaborative content manipulated by TV news.
\end{abstract}

\footnotetext{
*Doutor em Comunicação e Semiótica pela Pontifícia Universidade Católica de São Paulo (PUC-SP), mestre em Comunicação e Linguagens pela Universidade Tuiuti do Paraná (UTP) e graduado em Comunicação Social - Jornalismo pela Pontifícia Universidade Católica do Paraná (PUC-PR). Professor adjunto na Universidade Federal do Ceará (UFCE), líder do Centro de Estudos e Pesquisa em Jornalismo (CNPq). Email: ecajazeira@hotmail.com
} 
Therefore, the paper aims to verify the selection criteria of the statements made by addressers (journalists) and recipients (public) through the support of social spaces created by media companies on TV news and on the Internet.

Keywords: Tv news. Participation. Internet.

\section{Introdução}

Neste artigo, procura-se compreender a participação do telespectador de telejornal no processo de transição entre os períodos analógico e digital, por meio do ícone Fale Conosco na Internet, a fim de verificar as mudanças ocorridas no agendamento e na seleção das notícias com a criação dos novos espaços de interatividade entre destinadores e destinatários da informação.

A participação do público, no período analógico, se restringia apenas ao envio de cartas e telefonemas às redações do jornalismo em TV. Uma colaboração reduzida diante das limitações tecnológicas. Porém, com o advento das novas mídias digitais, esta relação mudou. A utilização das ferramentas web trouxe uma amplitude no contato entre o jornalismo e o seu público.

A busca por dados históricos quanto à prática dos leitores no envio de relatos, sugestões ou críticas aos jornais nos remete aos espaços, destinados na estrutura do planejamento editorial, conhecidos como "Cartas do Leitor" ou "Coluna do Leitor", que remontam ao início das publicações no século XIX.

A primeira "carta do leitor", nos moldes como hoje conhecemos, ocorreu na segunda parte do século XIX, em 18 de setembro de 1851, no jornal americano New York Times, cinco dias após o seu lançamento (SILVA, 2006). No Brasil, os primeiros jornais a publicarem cartas de leitores foram $O E S$ tado de São Paulo e a Folha de São Paulo, na época chamada Folha da Manhã, na década de 1950. Ou seja, quase um século após a primeira experiência do jornalismo impresso norte-americano.

A diferença entre a coluna Carta do Leitor do período analógico no jornalismo impresso e o atual Fale Conosco do telejornalismo em TV, através da Internet, está na natureza da participação do público, que pode ser desde um simples depoimento escrito com o relato de experiências pessoais a sugestões de pauta.
No entanto, a carta do leitor, apesar de ter um destinatário específico - o editor do jornal ou o jornalista que escreveu determinada reportagem - caracteriza-se por ser uma carta aberta, que pode ser publicada e lida por todos os leitores do meio de comunicação.

O e-mail do telespectador tem como único destinatário o departamento de jornalismo das emissoras de televisão e pode ser aberto a conhecimento do público ou não, dependendo do interesse jornalístico dos editores dos telejornais na sua utilização. Contudo, ambos possuem algumas particularidades em comum e divergências no conteúdo dos relatos.

Entre as particularidades se encontra o gênero textual, tanto das cartas quanto dos e-mails, que expressa a opinião (favorável ou não) do leitor/telespectador a respeito de determinado assunto publicado ou sobre o tratamento dado a algum tema com caráter mais polêmico. $\mathrm{O}$ autor, por meio da carta, pode esclarecer informações sobre o que foi publicado, além de sugerir novos assuntos e desdobramentos.

O conteúdo do texto intenciona persuadir o seu leitor (jornal). O formato é semelhante ao da carta pessoal, apresentando-se com uma linguagem pessoal (verbos na $1^{\mathrm{a}}$ pessoa do singular) ou impessoal (empregando pronomes e verbos na $3^{\mathrm{a}}$ pessoa); há ainda a possibilidade de utilização desses dois tipos de linguagem ao mesmo tempo com menor ou maior impessoalidade.

A mesma ocorrência discursiva se estabelece na mensagem eletrônica. No caso do telejornal, o sistema utilizado de recebimento deste tipo de mensagem se apresenta como um canal interativo de fluxo contínuo e imediato, que filtra os assuntos de interesse do público e os transforma, por meio de reportagens, em interesse público e os disponibiliza nos portais e sites de notícias.

Os telejornais, de modo geral, fazem um trabalho de triagem desses assuntos classificados como colaborativos, como ocorre nos jornalismo impresso, 
para selecionar, dentre os temas, aqueles que possuam maior abrangência.

O olhar do editor de jornalismo em TV está focado nos assuntos que sejam de grande impacto comum a um número expressivo de pessoas - e que na estrutura discursiva consiga gerar um interesse público já na leitura do enunciado. Esta seria uma das regras da produção jornalística em televisão: procurar focar em temas que atendam a uma parcela significativa da sociedade.

Desta forma, torna-se claro que, no discurso da mensagem colaborativa, o propósito está em debater esta ou aquela temática no telenoticiário de maneira ampla. O que diverge da Carta do Leitor, que se limita a publicar, após uma seleção prévia do editor (gatekeeper), as críticas aos temas das reportagens publicadas sem abrir a discussão ao debate público.

Em relação ao texto da mensagem colaborativa, a opção dos editores é pela utilização de conteúdos dramáticos. Na visão de Kenneth Burke citado por Cristina Pedraza Sêga (2011), considera-se uma ação dramática quando se incluem alguns elementos no texto, tais como conflito, propósito, reflexão e escolha. O dramatismo está, nesse caso, sendo usado como um instrumento de condução da mensagem para o suposto entendimento de grande parte do público na organização mental da informação.

Burke sistematizou que o dramatismo aproxima-se da ação da seguinte forma: sempre há um ato $(a c t)$ realizado por um ator ou agente numa dada situação ou contexto (scene). Para atuar ou agir, o ator inclui tudo que é conhecido acerca de sua substância, ou seja, todos os aspectos do seu ser, sua história, sua personalidade e quaisquer outros aspectos contribuintes. Para executar seu ato, o ator precisa de instrumento ou recursos (agency), e o ato só deve ser chamado como tal se ele envolver um propósito (purpose).

Assim, para saber os motivos que levam uma pessoa a agir por meio da ação, Burke sugeriu, em seu estudo, que sejam respondidas cinco questões: o que foi realizado (act); quando ou onde foi realizado (scene); quem realizou (agent); como ele realizou (agency) e por quê (purpose).

Este esquema, relacionado à prática de participação dos telespectadores no telejornal pelo canal Fale Conosco, revelou que a estrutura de identificação dos atos do público constrói-se da seguinte forma: a ação narrativa é vivenciada pelos sujeitos (quem) e descrita nos e-mails enviados ao departamento de telejornalismo da TV, demonstrando como se realizou a ação.

Isto denota que a procura do telespectador em participar não se restringe apenas à possibilidade de ter suas opiniões publicadas na TV, mas demonstra também a sua identificação com o tema, ao mesmo tempo em que expande as possibilidades do público em se comunicar através dos meios digitais.

Segundo John Thompson (2005), os meios eletrônicos colaborariam para que estas formas simbólicas continuem alcançando inúmeras audiências, fato incontestável pelos críticos da comunicação, "tornando possível uma quase-interação em que os comunicadores se tornam personalidades reconhecidas que podem falar diretamente aos receptores, e com as quais os espectadores podem simpatizar", além de usar expressões, símbolos e provérbios familiares aos receptores. Assim, as formas simbólicas colaborativas constroem-se como produtos através de palavras, atos, símbolos ou qualquer outra forma possível de ser interpretada e ressignificada pelo interlocutor.

\section{O papel de Gatekeeper e suas transforma- ções}

A função midiática do telejornal se transformou, ultrapassando a função de noticiar/informar. Agora, adota a função de intervir pedagogicamente, pois atribui a si outra responsabilidade social, porque quem produz a notícia é o interagente. Diante disso, as teorias do Gatekeeper e da Agenda Setting acompanham esta mudança no novo panorama do jornalismo. O sujeito/público, além participar como personagem coparticipante nas reportagens televisivas, agenda os assuntos que são discutidos, e, assim, redefinem-se as fronteiras do agendamento no espaço midiático.

Conforme Pereira Junior (2006), a figura do editor incorporou alguns comportamentos condicionados pela organização e pela comunidade profissional. $\mathrm{O}$ autor citou como se processou o surgimento da função de editor de jornalismo:

Na Segunda Guerra Mundial, era preciso acostumar-se as pessoas a substituir alimentos. O psicólogo social Kurt Lewin procurava entender o que 
determinava as decisões domésticas que levavam à compra da comida. Descobriu que demonstrar a necessidade de uma troca não bastava para que as pessoas mudassem de atitude. Essa motivação consciente só torna decisão assumida pelo consumidor se corresponder a desejos por ele nutridos. As pessoas podiam substituir alimentos. Alegariam motivação racional para a troca, quando na verdade pensaram fatores subjetivos na escolha. Quando fatores subjetivos se escondem sob critérios racionais, uma mudança se concretiza, concluiu. (PEREIRA JUNIOR, 2006, p. 32).

Em 1950, David Manning White aplicou o conceito ao jornalismo em um artigo da revista Journalism Quarterly. Anotou os motivos que levaram um jornalista veterano a rejeitar notícias num jornal médio americano. Queria entender o fluxo das notícias. Por que uns fatos viram notícias e outros não? Porque há um filtro, o gatekeeper, nome que remete a uma alfândega, um porteiro que filtra a entrada do que será noticiado.

White percebeu que regras profissionais são, como alegação, mais fortes que preferências pessoais para a seleção da notícia. Os gatekeepers são, em resumo, as formas de controle da informação criadas pelos veículos. Os critérios objetivantes, perseguidos pela teoria do gatekeepers, têm efeito colateral: a transferência de responsabilidade ética.

O conceito de gatekeeper consolida o que Nelson Traquina chama, na obra $O$ estudo do Jornalismo no século $X X$, de "teoria da ação pessoal", uma tradição forte entre as pesquisas sobre notícias. $\mathrm{O}$ autor mostra que a noção de gatekeeper de White é limitada para compreensão da imprensa e da notícia e enumera os três principais fatores desta ocorrência. O primeiro fator é porque, segundo Traquina, White analisa a informação jornalística só a partir do profissional que a produz, porque privilegia apenas uma abordagem "microssociológica", no nível do indivíduo, descartando fatores "macros" e até alguns "micros", como a empresa jornalística.

Como segundo fator observa-se que, para acentuar a ideia de seleção, a teoria da ação pessoal minimiza outras dimensões importantes do processo de produção das notícias. O terceiro fator diz respeito às conclusões de White, as quais foram confrontadas por outras pesquisas que demonstraram como o jornalista exerce a sua liberdade "dentro de uma latitude limitada".
Contudo, na era digital, esta figura do $g a$ tekeeper passa por uma transformação ao alternar e dividir com o seu público as funções de emissor e receptor das informações, bem como a seleção das notícias que serão publicadas. A informação colaborativa trouxe uma mudança no conceito de comunicação do telejornal. A mensagem jornalística exclusivamente transmissiva passa a ser receptiva com o uso de ferramentas web pelo leitor na convergência entre o telejornal e a internet.

O telespectador passivo torna-se um emissor ativo de mensagens diante da possibilidade que lhe foi ofertada, pelas empresas de comunicação, para participar, colaborar e auxiliá-las na cobertura de fatos diários. Por meio da produção de audiovisual, essa colaboração se manifesta, potencialmente, com forte teor de impacto e consequente aumento de audiência, visto que se abre ao público a possibilidade de coparticipar da notícia.

A ideia de passividade, que antes tomava conta dos olhares sobre a audiência, não condiz mais com esse novo cidadão, consumidor (CANCLINI, 1995) que de diversas formas ganha e ocupa cada vez mais espaços nas mídias tradicionais e contemporâneas.

Num tempo de grande facilidade de comunicação, manifesta-se também certa capacidade de inteligência e ação. "Saber fazer uso das técnicas é, para milhões de indivíduos, o sinal de uma emancipação e de uma maior igualdade social" (WOLTON, 2005).

$\mathrm{Na}$ era da midiatização, os cidadãos não se encontram munidos apenas com o uso do arsenal tecnológico. Além de dominar certos aparatos tecnológicos, grande parte da população também parece possuir certo domínio sobre a linguagem e os dispositivos jornalísticos.

O material colaborativo registrado pelo público, com pontos de vista, enquadramentos e ângulos de visão diferentes, poderá tornar-se notícia com alguns critérios jornalísticos na pré-seleção. Esse agendamento feito pelo público foi imposto pelas contínuas e profundas transformações sociais ocasionadas pela velocidade com que têm sido gerados os novos conhecimentos tecnodigitais, bem como a sua rápida difusão na sociedade, com trocas constantes de informação entre produtores e consumidores de notícias.

Essa pré-seleção gera um signo que, enviado ao telejornal, o seleciona e o adapta ao espaço do 
programa. Esta mudança, contudo, não se altera na leitura do público dos telejornais locais, que reconhece a notícia devido aos sinais indiciais de imagens trêmulas, enquadramentos irregulares, pouca iluminação durante a gravação e entre outras características comuns a imagens amadoras.

Este novo telespectador conectado às ferramentas multimídias digitais está com um olhar atento ao espetáculo do cotidiano em seu entorno. Lembrando Canclini (2008), a designação de espectador aplica-se a quem assiste a um espetáculo público ou "olha com atenção", segundo citado pela Enciclopédia Salvat na edição de 2003. A palavra posterior, espetáculo, além de fazer referência à sessão ou diversão, "celebrada num local ou lugar onde as pessoas se congregam para presenciá-lo", é definida como "ação que provoca estranheza ou escândalo. Usa-se especialmente com o verbo dar".

Esse novo espectador urbano não se contenta em apenas assistir aos espetáculos públicos na mídia, mas quer fazer parte dessa construção do real nos jornais, como participante/enunciador e personagem das reportagens, das quais, além de confirmar a veracidade do assunto reportado durante a exibição da TV, coparticipa da sua produção.

Em contrapartida, as empresas brasileiras de comunicação têm dado continuidade a uma sequência de testes, com transmissões experimentais, em formato digital para conseguir acompanhar essas mudanças ocorridas na era digital. Encontramo-nos apenas no "olho do furacão", como disse a pesquisadora Maria Lúcia Santaella (2008), ao afirmar que as mudanças e inovações no universo digital são exponenciais.

As convergências entre ciência, tecnologia, mídias e arte estão apenas começando. Os modelos tradicionais de pensamento sobre a arte não dão mais conta dos novos modos de sentir provocados pela sincronia da aceleração tecnológica com as novas reconfigurações da dimensão estética nos trabalhos daqueles que avançam na exploração de novas poiesis. Tanto sob efeito do enxame de dispositivos móveis que se colam à movimentação do corpo quanto da interação do agente participante com a informação em ambientes multidimensionais. (SANTAELLA, 2008, p. 15).

A pesquisadora fez esta afirmação num contexto original de estética recortada pela aceleração tecnológica ao analisar as condições propiciadas pelos aparelhos, dispositivos e suportes tecnológicos que, desde a invenção da fotografia até os hibridismos permitidos pelo ciberespaço e pelas invenções tecnocientíficas contemporâneas, ampliam sua participação de modo vertiginoso e transformam as bases materiais e os potenciais dos modos de produção estéticos.

Essa aceleração tecnológica colocada no contexto da produção colaborativa digital da nova linguagem do telejornalismo traz profundas consequências. Verifica-se que os sujeitos - público e telejornal - necessitam compreender os "novos modos de sentir provocados pela sincronia da aceleração tecnológica", a partir do significado de trocas no compartilhamento de dados e informações tecnodigitais e que, por muito tempo, colocaram em modelos de polos equidistantes os emissores e os receptores de mensagens. A transição do sistema analógico para o sistema digital nas mídias massivas alterou, por completo, o processo comunicativo das informações nos telejornais contemporâneos.

\section{As mudanças ocorridas na teoria do agen- damento}

Quanto à Teoria do Agendamento, de acordo com o professor português Nelson Traquina (2003), ela surgiu a partir de estudos dos pesquisadores norte-americanos McCombs e Shaw, durante as eleições presidenciais norte-americanas de 1968, e cuja publicação ocorreu em 1972. Eles se basearam numa amostra de cem eleitores indecisos como sendo provavelmente os mais abertos ou susceptíveis à informação eleitoral e que foram identificados e entrevistados pessoalmente durante dois meses.

A agenda pública de questões eleitorais destes eleitores era medida agregando as suas respostas a uma pergunta: "O que é que mais preocupa de momento? Isto é, independentemente do que dizem os políticos, quais são as duas ou três coisas principais acerca das quais pensa que o governo deveria fazer alguma coisa?".

As diferenças entre a pesquisa norte-americana e o tema deste estudo tornam-se evidentes quando hoje o público não apenas compartilha da opinião da imprensa sobre determinados assuntos discutidos na agenda midiática, mas busca agregar novos 
posicionamentos que, aceitos pelo destinatário, agendam outras discussões no ambiente midiático. Isto ocorre devido ao desejo constante do público em ser visto e de compartilhar posicionamentos. Uma situação que inexistia quando da realização da pesquisa norte-americana.

Verifica-se que as emissoras de TV, num período pré-novas mídias, enviavam equipes de jornalismo a vários locais em um mesmo dia para a cobertura da agenda dos telejornais. Hoje, a produção de jornalismo das TVs continua cobrindo os principais assuntos, mas com a diferença de que a participação do telespectador, incentivada de várias maneiras pela própria emissora, colabora com a produção jornalística.

Tal situação se configura como um modo de compartilhar com o público a elaboração da agenda midiática, aumentar a audiência e reduzir os custos de produção. Nesse novo sistema de mediação, vê-se o poder comunicativo do público ao trocar com o jornalismo as funções de emissor e receptor no agendamento.

O confronto entre a seleção sobre o que importa ao público como notícia e o que realmente ele gostaria de ver nos mass media permite construir hipóteses que reveem as teorias do agendamento, apesar de a possível participação do pseudo destinatário/destinador interferir no sentido de colocar em pauta aquilo que gostaria de ver discutido na mídia. $\mathrm{O}$ agendamento reflete, então, na construção desses discursos, as preferências desse público.

O público seleciona os assuntos do cotidiano agendando temas que poderiam ser inseridos nas conversas entre as pessoas. Esta ação, antes feita exclusivamente pelo jornalismo, agora compartilha deste poder. Porém, apesar da atuação do agendamento, não se pode deixar de levar em consideração que o público, antes indefeso, conseguiu mudar a ordem das coisas e levar à mídia os temas do seu próprio interesse, atenuando a imposição da imprensa.

Na perspectiva da agenda setting, pode-se observar uma sociologia cognitiva, onde os indivíduos adquirem sua visão de mundo proveniente da agenda estipulada, ao longo do tempo, pelos mass media. O efeito é ressaltado pelo seu aspecto cumulativo. A mesma assimetria constata-se nesta abordagem referente à força dos mass media e a fragilidade do público ou dos indivíduos. (FERREIRA, 2001, p. 112).
No caso do Fale Conosco, quando se trata de denúncias sobre a qualidade dos serviços públicos essenciais (saneamento, esgotos, transporte, saúde pública, segurança, educação ou asfaltamento), a participação do público permite ou impõe outro agendamento, que o leva a influenciar a opinião de outros telespectadores. Estabelece-se a representação midiática que traz à luz o valor e a força simbólica de toda uma comunidade local e não de apenas uma pessoa sobre determinado fato do cotidiano.

A opinião individual, quando discutida em uma esfera midiática, redireciona o assunto para auscultar as opiniões coletivas. Nesse novo sistema de interação, os indivíduos podem assumir um posicionamento de concordância e vontade de colaborar com a TV para a gravação de enunciados com a identificação de outros problemas semelhantes ocorridos na comunidade local. Ao fazê-lo, agendam os assuntos de interesse que desejam ver reportados no jornal.

O espaço do noticiário não é somente um lugar em que se reproduzem os acontecimentos sob a maior ou menor responsabilidade dos atores políticos e cidadãos. É também o lugar de construção da opinião, pois é igualmente considerado lugar de surgimento e de confronto de palavras, que revelam análises feitas a respeito dos acontecimentos sociais e dos julgamentos emitidos sobre a significação destes.

Portanto, representa um espaço de debates em sentido amplo, isto é, de troca entre os participantes da vida social, que, a um só tempo, se baseia na simbólica democracia. Os sentidos são distintos e contribuem para lhe dar vida, ao permitir que a verdade seja submetida à deliberação (CHARAUDEAU, 2007).

O público deixa de ser "espectador" e se torna, também, um usuário colaborativo. Além disso, os usuários começam a discutir suas obras, criar coletivos de realização e rever o conceito clássico de autoria individual. Assim, com as possibilidades do digital, efetiva-se a democracia audiovisual, resultante da descentralização da produção e da criação de redes de produtores organizadas de forma não hierárquica. (CANNITO, 2010, p. 183).

Conforme Alberto Dines (2009, p.73) “o emissor se alterna nas suas funções enunciativas durante o processo de mediação das informações e cada 
emissor é simultaneamente um receptor e vice-versa, o que caracteriza o sistema como múltiplo, funcionando em todas as direções". O jornalista e o leitor fazem parte de um mesmo contexto social; em última análise, são a mesma coisa.

É por essa razão que não se pode dizer que a imprensa de determinado país ou região é ruim ou boa, mas ela é reflexo e segmento da própria sociedade a que serve. Jornalista e leitor são os que melhor se entendem e sintonizam, pois se os primeiros são treinados para sentir as necessidades do último, este foi preparado para receber aquilo que certamente lhe agradará.

O posicionamento de Alberto Dines (2009) diz muito sobre como o jornalista procura colocarse na função de destinatário (leitor) antes de tornarse o destinador da informação, pois o jornalista é o leitor em função de emissão. Como afirma o autor, "treinados para sentir as necessidades do último", ele (jornalista) seleciona as informações baseado em critérios de noticiabilidade dos fatos que verificam, além da autenticidade, a amplitude e a abrangência, pois assim produzirão interesse nas necessidades de informação do público.

A efetivação da tecnologia digital influenciou todas as etapas desse sistema múltiplo de recepção e emissão com novas técnicas de captação e distribuição. No aspecto da interpretação da imagem individual, a realidade que a mídia constrói do enunciado do público fundamenta-se no desejo do destinador/ TV em criar uma identidade real midiática, na qual o público se reconheça como cidadão pertencente a um determinado grupo social. Nesse sentido, existe uma relação política da televisão com o seu público e uma antecipação da agenda pública numa mostra de autovisibilidade do meio de comunicação em discutir assuntos sociais em esferas midiáticas.

Existir uma evidente disposição do público em participar dessa discussão e da organização da agenda midiática na condição de coparticipante que agenda a imprensa. O público interfere nas discussões da agenda pública e procura externar sua opinião individual com a elaboração de textos que reproduzem um retrato pessoal sobre o cotidiano das cidades nessa nova fase de interações digitais e constantes trocas nas funções comunicativas no telejornalismo.

\section{Referências}

CANNITO, Newton. A televisão na era digital: interatividade, convergência e novos modelos de negócio. Summus Editorial, 2010.

CHARAUDEAU, Patrick. Discurso das mídias. São Paulo: Contexto, 2007.

DINES. Alberto. O papel do jornal e a profissão de jornalista. 9 ed. São Paulo: Summus Editorial, 2009.

FERREIRA. Giovandro Marcus. Teorias da comunicação trajetórias investigativas. Salvador: Edufba, 2001

KUNCZIK, Michael. Conceitos de jornalismo: norte e sul. São Paulo: Edusp, 2002.

PEREIRA JR., Luis Costa. Guia para edição jornalística. Petrópolis: Vozes, 2006.

SANTAELLA, L.; NÖTH, W. Imagem: cognição, semiótica, mídia. 4 ed. São Paulo: Iluminuras, 2005.

;ARANTES, Priscila (Org.). Estéticas tecnológicas: novos modos de sentir. São Paulo: Editora da PUCSP, 2008.

SÊGA, Christina Pedraza. Sociedade e interação: um estudo das diferentes formas de interagir. Brasilia: Editora UnB, 2011.

SILVA, Marisa Torres. As "cartas ao director" no jornal Público: um estudo de caso. Disponível em: http://www. bocc.ubi.pt/pag/silva-marisa-cartas-director-jornal-publico. pdf. Acesso em: 15 junho 2011.

THOMPSON. John. A mídia e a modernidade: uma teoria social da mídia. Petropolis: Vozes, 2004.

Teorias do Jornalismo: a tribo jornalística: uma comunidade interpretativa transnacional. 2.ed. Florianópolis: Insular, 2008.

TRAQUINA, Nelson. Teorias do jornalismo: porque as notícias são como são. 2 edição. Florianópolis: Insular, 2005.

WOLF, Mauro. Teorias da comunicação. 4 ed. Lisboa: Presença, 1995.

WOLTON, Dominique. É preciso salvar a comunicação. São Paulo: Paulus, 2005.

Elogio do grande público: uma teoria crítica da TV. São Paulo: Ática, 1996.

Recebido em: 30 de setembro de 2011 Aceito em: 30 de julho de 2012 